\title{
Measurement of Carbon Dioxide and Methane in Forest Soils Following Uncontrolled Wildfires in the Coconino National Forest
} Timothy L. Porter $^{{ }^{*}}$ and Thomas R. Dillingham ${ }^{2}$

${ }^{1}$ University of Nevada Las Vegas, Department of Physics and Astronomy, Las Vegas, NV, 89154, USA

${ }^{2}$ Northern Arizona University, Department of Physics and Astronomy, Flagstaff, AZ, 86001, USA

\begin{abstract}
We have used a portable, battery-powered quadrupole mass spectrometer to measure the relative concentrations of carbon dioxide $\left(\mathrm{CO}_{2}\right)$, methane $\left(\mathrm{CH}_{4}\right)$, and water vapor in soils of the Coconino National Forest. In particular, we have compared the soil gas levels in regions of the forest that have been untouched with regions that have suffered wildfire damage. With some exceptions, our results tend to indicate that both the soil $\mathrm{CO}_{2}$ concentration and the soil $\mathrm{CH}_{4}$ concentrations decrease somewhat as the severity of the forest damage increases through the timing of the fire and subsequent forest regrowth. In some cases, soil water vapor content appears to have played a significant role in the concentrations of these gases as well. Further measurements over longer periods of time are required to more exactly quantify the role played by many different variables in the local concentrations of important forest soil gases.
\end{abstract}

\section{Publication History:}

Received: January 06, 2020

Accepted: March 02, 2020

Published: March 04, 2020

\section{Keywords:}

Carbon dioxide, Forest, Methane, Quadrupole, Soil, Wildfire

\section{Introduction}

The effect of uncontrolled wildfires on forest ecosystems is devastating. In addition to the severe local damage within the forest itself, long-term environmental effects on scales much larger than the forest system may occur. During fires, very large amounts of $\mathrm{CO}_{2}$ and other gases are initially released into the atmosphere. After the fires, however, massive changes to the forest vegetation and soils may have decades-long effects on the environment. One of the most important environmental impacts owing to wildfires is the alteration of environmentally important atmospheric gases [1]. The net flux of gases from all forest sources such as $\mathrm{CO}_{2}$ and $\mathrm{CH}_{4}$ have been shown to decrease and increase, respectively, after fires $[1,2]$. Less is known, however, regarding the specific contents of the soil component of the total forest gas contributions. Accurate measurements of soil gases in situ may help to model the processes within the soils that ultimately lead to net production or uptake of greenhouse gases in forest soils.

Forests play a significant role in the both the production and removal of greenhouse gases in the atmosphere such as $\mathrm{CO}_{2}$ and $\mathrm{CH}_{4}$. Forest soils contribute significantly to $\mathrm{CO}_{2}$ in the atmosphere through a process referred to as soil respiration. Accounting for all soils worldwide, the respiration process may contribute between $20 \%$ and $40 \%$ of all $\mathrm{CO}_{2}$ released into the atmosphere from all sources $[3,4]$ It has been shown that up $70 \%$ of $\mathrm{CO}_{2}$ flux within temperate forests originates within the soils [5-7].

The net flux of soil $\mathrm{CO}_{2}$ may vary significantly depending upon temperature [8,9], soil compaction, soil composition, root structure within the soil $[10,11]$, and decaying forest components within the soil [12]. The amount of nitrogen in the soil affects respiration through soil carbon allocation effects, effects of soil microbe activity, and through root respiration and litter decomposition $[13,14]$. Respiration in forest soils is also affected by the water content in the soil $[15,16]$. It has been shown that $\mathrm{CO}_{2}$ production falls in forest soils that are either too wet or too dry, and peaks under optimal soil moisture conditions [17]. These factors contributing to soil respiration in forests may change over extended periods of time owing to the effects of wildfires.

In the case of $\mathrm{CH}_{4}$, forest soils may act as $\mathrm{CH}_{4}$ sinks in some cases and as $\mathrm{CH}_{4}$ sources in other cases [18-20]. In oxygenated soils, methanotrophic bacteria consume $\mathrm{CH}_{4}$ in an oxidation reaction with
$\mathrm{O}_{2}$ present within the soil. This $\mathrm{CH}_{4}$ consumption process within the soil produces $\mathrm{CO}_{2}$, which may subsequently diffuse through the soil and be emitted to the atmosphere. $\mathrm{CH}_{4}$ may also be produced under certain conditions in soils. In an anaerobic environment, microorganisms consume carbon containing organic matter found in the soils, giving rise to $\mathrm{CH}_{4}$ production [21]. $\mathrm{CH}_{4}$ production may also occur abiotically in intact plant tissue or forest litter, some of which may exist in forest soils [18]. The presence of water in the soils may play a key role in determining whether bacteria in the forest soil act as net producers or as net sinks of $\mathrm{CH}_{4}$. It has been reported that forest soils may transition to net producers of $\mathrm{CH}_{4}$ as opposed to $\mathrm{CH}_{4}$ sinks as the topmost layers of the soil become dryer [22]. It was postulated that the oxidation of $\mathrm{CH}_{4}$ was significantly reduced in the dryer topmost soil layers, thereby removing the largest process leading to $\mathrm{CH}_{4}$ removal in the soils. This reduced oxidation of $\mathrm{CH}_{4}$ may have been the result of water loss and thus degradation of the bacteria themselves, or simply more rapid diffusion of $\mathrm{CH}_{4}$ out into the atmosphere as a result of water loss in the soils, ultimately resulting in less time for $\mathrm{CH}_{4}$ oxidation by bacteria to occur $[20,22]$. When forests burn, many changes may occur that affect the $\mathrm{CH}_{4}$ cycle in the forest soil. These changes may include loss or changes in soil organic matter, loss or changes in soil microbes, and changes in forest soil water content. These wildfire-induced changes may alter $\mathrm{CH}_{4}$ reduction or production for years or decades after the fires.

In the current study, we have used quadrupole mass spectrometry to perform real-time, high sensitivity measurements of the near surface soil concentrations of the gases $\mathrm{CO}_{2}, \mathrm{CH}_{4}$, and water vapor in the forest soils of the Coconino National Forest in Flagstaff, Arizona, USA. The goal of this study is to compare the relative ratios of soilproduced greenhouse gases in pristine forest areas to forest areas that

"Corresponding Author: Prof. Timothy Porter, University of Nevada Las Vegas, Department of Physics and Astronomy, Las Vegas, NV, 89154, USA; E-mail: tim.porter@unlv.edu

Citation: Porter TL, Dillingham TR (2020) Measurement of Carbon Dioxide and Methane in Forest Soils Following Uncontrolled Wildfires in the Coconino National Forest. Int J Earth Environ Sci 5: 176. doi: https://doi.org/10.15344/2456351X/2020/176

Copyright: (c) 2020 Porter et al. This is an open-access article distributed under the terms of the Creative Commons Attribution License, which permits unrestricted use, distribution, and reproduction in any medium, provided the original author and source are credited. 
Citation: Porter TL, Dillingham TR (2020) Measurement of Carbon Dioxide and Methane in Forest Soils Following Uncontrolled Wildfires in the Coconino National Forest. Int J Earth Environ Sci 5: 176. doi: https://doi.org/10.15344/2456-351X/2020/176

have been partially or severely damaged in wildfires. While these first comparison measurements are preliminary, they may provide initial guidance into the short, medium, and long-term effects of forest wildfires on soil respiration of greenhouse gases and eventual emissions of these gases into the atmosphere.

\section{Materials and Method}

The instrument was described in detail in a previous communication. Briefly, the mass spectrometer we use can analyze masses in the range of 0-300 AMU and can measure partial pressures down to $10^{-10}$ Torr The unit is portable and is carried in a case weighing approximately 33 pounds. Power for the system is provided by a Li-Ion 24-Volt battery pack. The vacuum system supporting the mass spectrometer consists of a Pfeiffer $41 / \mathrm{min}$ diaphragm pump for obtaining rough vacuum in the gas inlet system and simultaneously backing the turbo pump, and a Pfeiffer $10 \mathrm{l} / \mathrm{s}$ turbomolecular pump for obtaining high vacuum in the quadrupole analysis section of the instrument. A vacuum gauge provides data on system pressure outside of the analysis chamber, which contains its own integrated total pressure, monitor [23]. Figure 1 shows a photograph of this instrument in the Shultz fire area of the Coconino National Forest. A small laptop computer sits beside the mass spectrometer.
This gasinlet probe is designed to directly measure gas concentrations from soils. Gas at ambient pressure first passes through a $20 \mu \mathrm{m}$ orifice into a vacuum section of the instrument rough-pumped by the diaphragm pump. A second orifice of diameter $10 \mu \mathrm{m}$, isolates this rough pumped region from the high-vacuum, turbo-pumped analysis chamber. This system of differential pumping allows samples to be inlet from ambient air, and quickly enter the high-vacuum analysis region of the system. After approximately 15 minutes of operation, the analysis chamber pressure is reduced to approximately $1-2 \times 10^{-6}$ Torr. This ultimate pressure is essentially pinned at this value, determined by the gas load through the two inlet orifices. Field measurements in this study were taken with the mass spectrometer analysis chamber in this $1-2 \times 10^{-6}$ Torr vacuum range. During actual measurements, the quadrupole providedreal-time total pressure readings in the analysis chamber. At each location, four quadrupole measurements were taken with an approximately 15-30 sec time interval between measurements.

Measurements of soil gas concentrations were taken in July of 2019 in two areas near Flagstaff, AZ that have been previously affected by wildfires. The Shultz Fire area northwest of Flagstaff burned 15,000 acres in 2010. Here, we measured soil gas concentrations in areas totally destroyed by the fire, and in a section within the main burned area that suffered only moderate fire damage. We define a "totally"

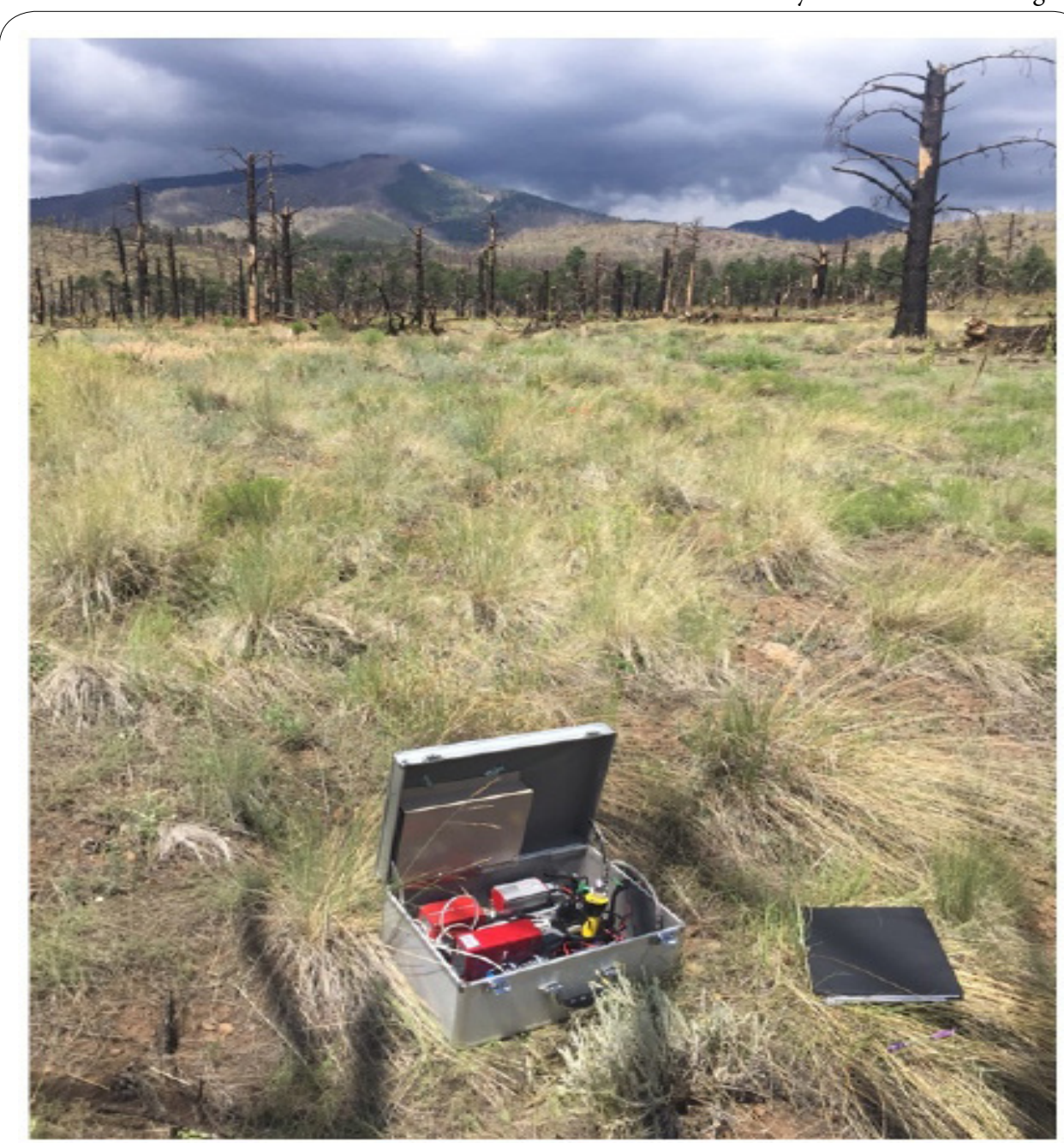

Figure 1: Photograph of this instrument in the Shultz fire area of the Coconino National Forest. A small laptop computer sits beside the mass spectrometer. 
Citation: Porter TL, Dillingham TR (2020) Measurement of Carbon Dioxide and Methane in Forest Soils Following Uncontrolled Wildfires in the Coconino National Forest. Int J Earth Environ Sci 5: 176. doi: https://doi.org/10.15344/2456-351X/2020/176

Page 3 of 6

burned area as one in which all trees were destroyed along with other vegetation, and a "moderately" burned area in which trees survived with some possible minor damage but grasses and smaller vegetation were burned. In the area destroyed by fire (2010), all trees, shrubs and grasses were $100 \%$ burned. In the 9 years between the fire and our measurements, the areas have been taken over by grasses and other small vegetation. Vegetation present included bouteloua curtipendula, poa fendleriana, eriogonum alatum, potentilla hippiana, and pseudocymopterus montanus. Also present were some small weed species such dalmatian toadflax and diffuse knapweed. There had been no tree regrowth during this time. In the section of the Schultz fire that was only moderately damaged in 2010 , vegetation included some partially burned trees including ponderosa pine and white fir, as well as the same grasses and weed species found in the totally burned areas. The second wildfire area studied was the "Cowboy" fire, which burned a smaller forest region south of Flagstaff in 2016. In the Cowboy fire region, the fire damage was total, with few surviving trees or smaller vegetation. In this area, no substantial regrowth of any grass, weed or other species had yet occurred in the area where measurements were taken.

Measurements taken in both the Shultz and Cowboy forest areas, as well as pristine forest areas were monitored for rainfall prior to field readings. In both cases, the areas under study received a minimum of 11 or 12 consecutive days of measurable rain prior to readings. Total rainfall in the days prior to measurement varied somewhat owing to the monsoon activity resulting in the precipitation, but water vapor concentrations in the soils measured provide a basis for comparison of readings. The ambient temperature during readings was between 17 and $18.2^{\circ} \mathrm{C}$., and measurements were taken between 1 and $3 \mathrm{pm}$ In each area measured, four readings were taken within a short time interval of $120 \mathrm{sec}$ or less.

\section{Results and Discussion}

We have conducted in-situ measurements of $\mathrm{CO}_{2}, \mathrm{CH}_{4}$, and water vapor directly within the soil of ponderosa pine forests burned by wildfires, and in nearby areas untouched by fires. We note that these measurements are not "total flux" gas measurements of the soils and top layer forest components, but simply relative gas concentrations within the top layers of the soils themselves. Figure 2 shows a photograph of the forest within the 2010 Shultz fire area of the Coconino National Forest. The effects of this 15,000-acrefire were devastating to life in this region. Large, old growth pine trees were completely destroyed, with most areas within the fire perimeter showing zero remaining tree canopy life. In Figure 3, a small area within the larger Shultz fire burn is shown. This area is only a few acres in size and suffered less damage to the forest than the majority of the Shultz burn. Approximately 5\% of the total 15,000 Shultz fire area was similar to this smaller, healthier region. The soil surface characteristics in this small area were like that of the major burn area in that forest grasses have regrown, but also included small amounts of pine needles, small dead wood pieces, and small numbers of pinecones from the remaining trees.

All gas concentration readings from the soils were performed in the same manner. A small diameter hole, approximately $1 \mathrm{~cm}$, was punched into the soil. The inlet probe to the mass spectrometer was inserted approximately $2.5 \mathrm{~cm}$ into the hole, with a snug fit around the cylindrical input probe. The ground level was sealed by outside pressure using a $3.4 \mathrm{~cm}$ diameter steel flange. With the inlet probe sealed in place, the pumping system was started, and tiny amounts of air within the soil-probe area began to be drawn into the system. The system was allowed to come to vacuum equilibrium for 10-15 minutes, after which the quadrupole analyzer was switched on and readings were taken. Four separate readings were recorded at each location, taken in succession with approximately $15-30 \mathrm{sec}$ between each reading.

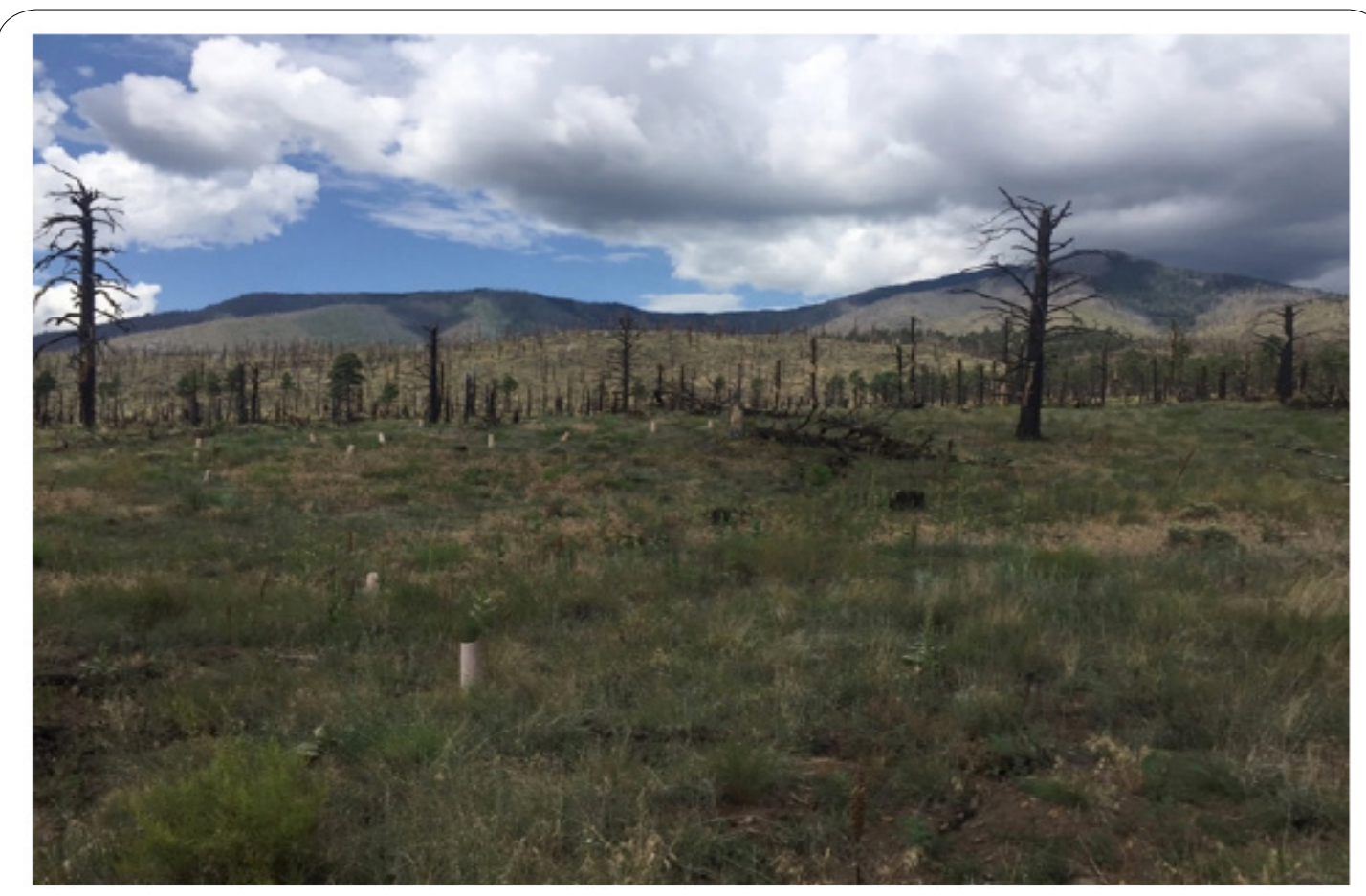

Figure 2: Photograph of the forest within the Shultz fire area of the Coconino National Forest. Many small white PVC cylinders contain small, replanted ponderosa pine trees as part of the forest restoration project. The ground is populated with grasses, weeds, and small shrubs or bushes. The soil in this region was covered with an approximately 1-inch thick layer, consisting mostly of dead grasses and shrub or bush litter. 
Citation: Porter TL, Dillingham TR (2020) Measurement of Carbon Dioxide and Methane in Forest Soils Following Uncontrolled Wildfires in the Coconino National Forest. Int J Earth Environ Sci 5: 176. doi: https://doi.org/10.15344/2456-351X/2020/176

Table 1 shows factor differences from air baselines (baselines = 1.0) for pristine forest soil, and forest soils burned in the 2010 Shultz fire. Each factor difference at a given location is reported as the mean factor difference from four separate measurements plus or minus the standard deviation factor difference. Data for Shultz fire regions include the majority, heavily burned areas (95\% of total burned acreage) and the less damaged, minor areas within the overall Shultz fire area. Compared to soils in pristine forest areas, the $\mathrm{CO}_{2}$ levels in the primary Shultz region were lower by $30 \%$, but still almost double that of above ground air $\mathrm{CO}_{2}$ levels. In the lesser burned regions of the fire, the measured $\mathrm{CO}_{2}$ was $57 \%$ lower than in pristine forest soil, and 38\% lower than in the major Shultz burn area. CH4levels in both Shultz fire areas were below ambient air levels.

\begin{tabular}{|l|l|l|l|}
\hline & $\mathrm{CO}_{2}$ & $\mathrm{CH}_{4}$ & Water Vapor \\
\hline Pristine Forest Soil & $2.76 \pm .03$ & $0.63 \pm .01$ & $1.40 \pm .02$ \\
\hline Burned (Shultz) & $1.92 \pm .02$ & $0.38 \pm .02$ & $1.44 \pm .03$ \\
\hline Burned Forest (Shultz Minor) & $1.20 \pm .03$ & $0.85 \pm .01$ & $1.17 \pm .015$ \\
\hline
\end{tabular}

Table 1: Factor differences from air baselines (baselines $=1.0$ ) for pristine and forest soils burned in the 2010 Shultz fire. A few acres section of the Shultz fire suffered less overall damage and is shown as the Shultz fire (minor). In the burned forest, the $\mathrm{CO} 2$ soil level is 0.70 that of the pristine forest soil and methane is 0.60 of the pristine level.
Compared to pristine forest soil concentration, the primary Shultz soil had a $40 \%$ lower $\mathrm{CH}_{4}$ level, and the lesser burned Shultz area had a $35 \%$ higher $\mathrm{CH}_{4}$ concentration. The primary Shultz fire area soil water vapor concentration was consistent with most other measured forest areas at about $40-45 \%$ higher than above ground levels, but the minor Shultz fire area showed a lower water vapor reading only $17 \%$ higher than above ground levels.

In Figure 4, a photo of a section of the 2016 Flagstaff Cowboy fire is shown. In this area, most or all of the forest life was burned or destroyed. Some tree canopy remained. We estimate approximately $0-15 \%$ of the original pine tree canopies survived this area of the fire. On the ground, there was very little living vegetation observed, as this fire burned in 2016, however there was a small layer of pine needles on the ground owing to the remaining pine tree life.

In Table, 2 factor differences from air baselines for pristine and forest soils burned in the 2016 Cowboy fire are shown. The measured $\mathrm{CO}_{2}$ concentration is $60 \%$ that of the $\mathrm{CO}_{2}$ level in pristine forest soil and the $\mathrm{CH}_{4}$ level is $44 \%$ of the normal forest. This level of $\mathrm{CH}_{4}$ is the lowest we have measured in any forest soil.

As mentioned earlier, soil $\mathrm{CH}_{4}$ net flux is ultimately determined by the aerobic removal of $\mathrm{CH}_{4}$ by microbes that consume $\mathrm{CH}_{4}$ in an oxidation reaction with $\mathrm{O}_{2}$ present in the soil, versus the anaerobic

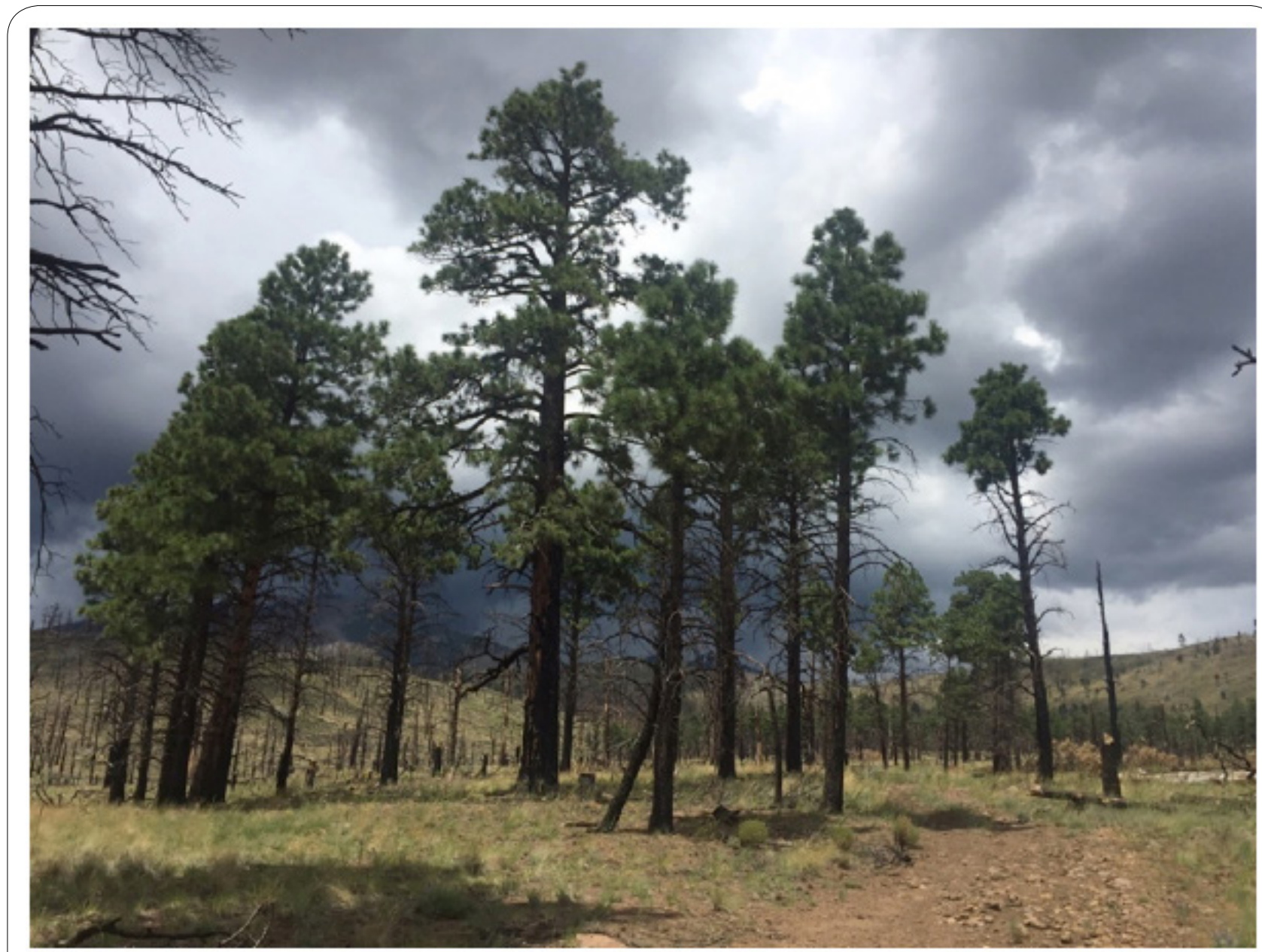

Figure 3: A small area within the larger Shultz fire burn is shown. This area is only a few acres in size and suffered less damage to the forest than most of the Shultz burn. Approximately $5 \%$ of the 15,000 Shultz fire areas were similar to this small region. 
Citation: Porter TL, Dillingham TR (2020) Measurement of Carbon Dioxide and Methane in Forest Soils Following Uncontrolled Wildfires in the Coconino National Forest. Int J Earth Environ Sci 5: 176. doi: https://doi.org/10.15344/2456-351X/2020/176

Page 5 of 6

production of $\mathrm{CH}_{4}$ by microorganisms that consume carbon containing organic matter found in the soils. Precise soil conditions that lead to either the production or removal of $\mathrm{CH}_{4}$ are varied, and there is a potentially complex interplay between different soil variables making analysis and modeling difficult. Here, we have found soil $\mathrm{CH}_{4}$ concentrations that tend to decrease as the severity, or overall damage caused by the fire increases. Within the large Shultz fire area of approximately 15,000 acres, there are areas of forest that were only partially burned, leaving a percentage of the tree canopies intact, but burning much of the other vegetation. Soil $\mathrm{CH}_{4}$ concentration measured in one of these areas was slightly higher than that found in an unburned, pristine forest soil. In the more severely burned areas of the Shultz fire, representing the vast majority of the total acreage burned, soil $\mathrm{CH}_{4}$ levels decreased by $55 \%$. Finally, in the more recent Cowboy fire, with very little living vegetation present, the soil $\mathrm{CH}_{4}$ level decreased by $67 \%$ over the less burned Shultz fire area. Soil water vapor concentrations were consistent with each other and with previous measurements at about $50 \%$ higher than above ground levels, with the single exception being in the less-burned Shultz area where the water concentration was only about $17 \%$ above ambient levels. It is possible that the soil $\mathrm{CH}_{4}$ concentration found here, $26 \%$ higher than in an untouched forest soil, was due to this smaller water vapor content. Studies by others have shown that $\mathrm{CH}_{4}$ producing bacteria may thrive in soils that are somewhat drier than others. Otherwise, our results tend to indicate lower $\mathrm{CH}_{4}$ levels in soils that have suffered greater or more recent fire damage.

In the case of $\mathrm{CO}_{2}$, our results show all three burned forest areas exhibit soil $\mathrm{CO}_{2}$ levels that are lower that found in unburned, nonthinned forests. In the primary Shultz fire area, we measured soil $\mathrm{CO}_{2}$ concentration to be $30 \%$ lower than in pristine forest, and soil $\mathrm{CO}_{2}$ concentration in the recent Cowboy fire region to be $40 \%$ lower. Within the partially burned Shultz area, we measured soil $\mathrm{CO}_{2}$ concentration to be $57 \%$ lower than in pristine forest. While we might

\begin{tabular}{|c|c|c|c|}
\hline & $\mathrm{CO}_{2}$ & $\mathrm{CH}_{4}$ & Water Vapor \\
\hline Pristine Forest Soil & $2.76 \pm .03$ & $0.63 \pm .01$ & $1.40 \pm .02$ \\
\hline Burned Forest (Cowboy) & $1.66 \pm .04$ & $0.28 \pm .01$ & $1.42 \pm .03$ \\
\hline \multicolumn{4}{|c|}{$\begin{array}{l}\text { Table 2: Factor differences from air baselines (baselines }=1.0 \text { ) for } \\
\text { pristine and forest soils burned in the } 2016 \text { Cowboy fire. In the } \\
\text { burned forest, the } \mathrm{CO}_{2} \text { soil level is } 0.60 \text { that of the pristine forest soi } \\
\text { and } \mathrm{CH}_{4} \text { is } 0.44 \text {. }\end{array}$} \\
\hline
\end{tabular}

expect $\mathrm{CO}_{2}$ levels in the partially burned Shultz fire area to be higher than that in the more heavily burned areas, the significantly lower soil water vapor concentration may again be the primary reason why. Respiration in forest soils has been shown to be affected by the water content in the soil $[15,16]$. It has been shown that $\mathrm{CO}_{2}$ production falls in forest soils that are either too wet or too dry, and peaks under optimal soil moisture conditions [17]. The Cowboy fire area was the most recently burned, and had little or no vegetation present; while the primary Shultz fire region burned many years previously and now have grasses and small bushes and weeds growing. We may expect then that the older, recovering burned site may have greater microbial carbon in the soil and thus a larger production of $\mathrm{CO}_{2}$ that the more recently burned site does. Our goal for these burned areas is to return to the exact sites measured in the current study and repeat the same measurements under the same temperature and soil humidity conditions. This will give us comparison data on the soil respiration processes as the forest vegetation regrows slowly over the years.

\section{Conclusions}

We have demonstrated that a portable quadrupole mass spectrometer can rapidly and accurately measure relative concentrations of forest soil gases such as $\mathrm{CO}_{2}$ and $\mathrm{CH}_{4}$. The effects of wildfires on these soil gas levels has been measured and compared to pristine, unburned forests. Generally, the soil concentrations of $\mathrm{CO}_{2}$ are lower for soils that

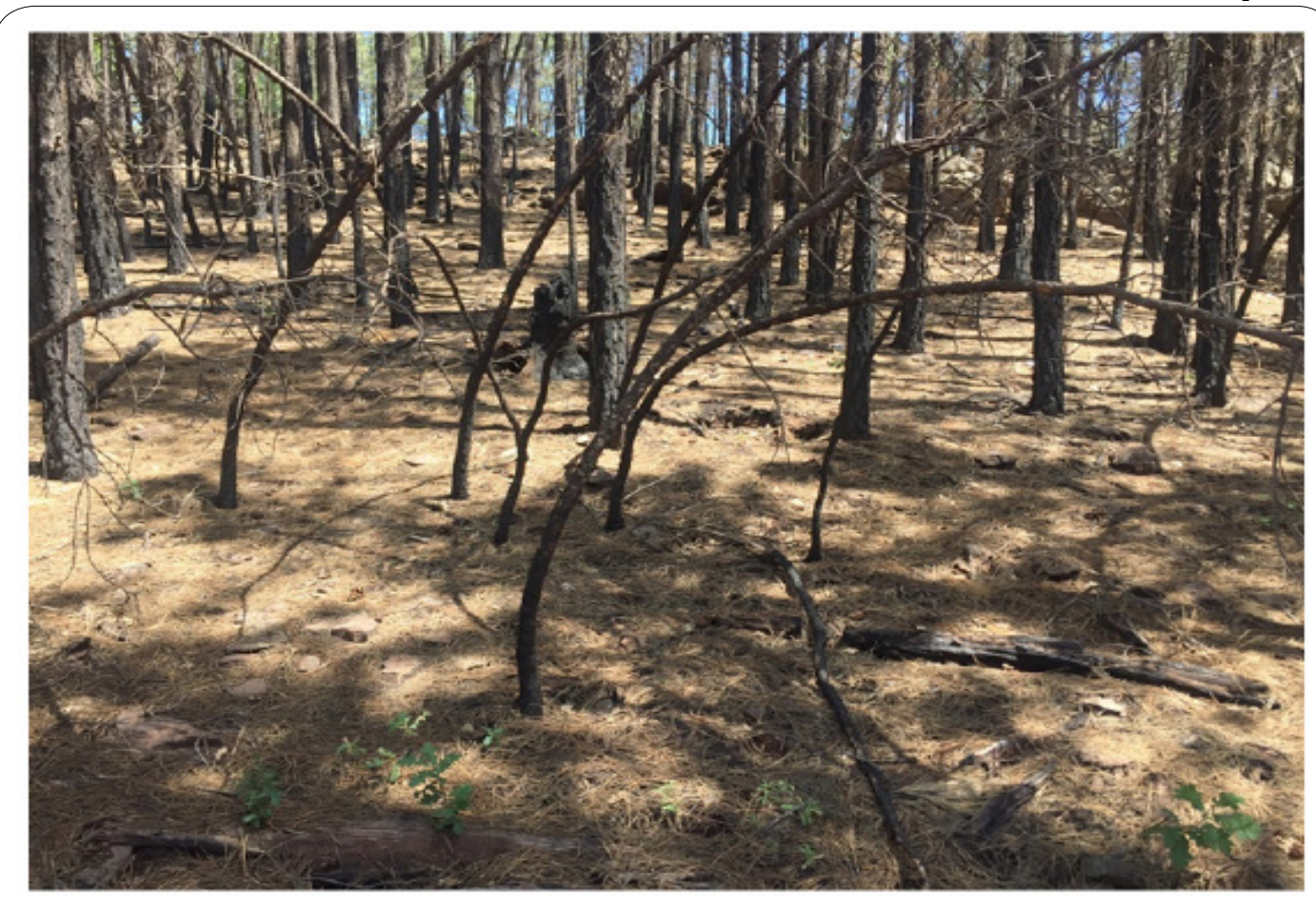

Figure 4: Photo of a section of the 2016 Cowboy fire. In this area, most or all of the forest life was burned or destroyed. Compared to the 2010 Shultz fire, there has not been sufficient time for the soil level grasses to regrow. 
Citation: Porter TL, Dillingham TR (2020) Measurement of Carbon Dioxide and Methane in Forest Soils Following Uncontrolled Wildfires in the Coconino National Forest. Int J Earth Environ Sci 5: 176. doi: https://doi.org/10.15344/2456-351X/2020/176

Page 6 of 6

have more recently burned or suffered greater damage than for soils in unburned forests. $\mathrm{CH}_{4}$ concentrations show a similar decreasing pattern as the nature and time of the fire are considered. Other factors, however, such as soil water content, may play a significant role in the local fluxes of both of these gases. Future measurements under drier conditions, prior to seasonal monsoon activity, will help us model the soil gas fluxes as the burned forest areas recover over many years. With this instrumentation, we may begin to track the concentrations of soil gases over longer periods of time to study the evolution and relationship between gases produced in forest soils and the structure and health of the forest itself.

\section{Competing Interests}

The authors declare that they have no competing interests.

\section{References}

1. Hu T, Sun L, Hu H, Guo F (2017) Effects of Fire Disturbance on Soil Respiration in the Non Growing Season in a Larix Gmelinii Forest in the Daxingan Mountains, China. PLoS One 12: e0180214.

2. Sullivan BW, Kolb TE, Hart SC, Kaye J, Hungate BA, et al. (2011) Wildfire Reduces Carbon Dioxide Efflux and Increases Methane Uptake in Ponderosa Pine Forest Soils of the Southwestern USA. Biogeochemistry 104: 251-265.

3. Raich JW, Schlessinger WH (1992) The Golbal Carbon Dioxide Flux in Soi Respiration and its Relationship to Vegatation and Climate. Tellus. 44: 8199.

4. Bond-Lamberty B, Thomson A (2010) Temperature Associated Increases in the Golbal Soil Respiration Record. Nature. 123: 99-117.

5. Gouklen ML, Munger JW, Fan SM, Daube BC, Wofsy SC, et al. (1996) Measurements of Carbon Sequestration by Long Term Eddy Covariance Methods in a Critical Evaluation of Accuracy. Global Change Biol 2: 169-182.

6. Law BE, Ryan MG, Anthoni PM (1999) Seasonal and Annual Respiration in a Ponderosa Pine Ecosystem. Global Change Biol 5: 169-182.

7. Davidson EA, Janssens LA (2006) Temperature Sensitivity of Soil Carbon Decomposition and Feedbacks to Climate Change. Nature. 440: 165-173.

8. Parkin TB, Kaspar TC (2003) Temperature Controls on Diurnal Carbon Dioxide Flux. Soil Science Society of America Journal 67: 1763-1772.

9. Londo AJ, Messina MG, Schoenholtz SH (1999) Forest Harvesting Effects on Soil Temperature, Moisture, and Respiration in a Bottomland Hardwood Forest. Soil Society of America Journal 63: 637-644.

10. Hanson PJ, Edwards NT, Garten CT, Andrews JA (2000) Seperating Root and Soil Microbial Contributions to Soil Respiration: A Review of Methods and Observations. Biogeochemistry 48: 115-146.

11. Högberg P, Nordgren A, Buchmann N, Taylor AF, Ekblad A, et al. (2001) Large Scale Forest Girdling Shows That Current Photosynthesis Drives Soi Respiration. Nature 411: 789-792.

12. Billings SA, Richter DD, Yarie J (1998) Soil Carbon Dioxide Fluxes and Profile Concentrations in Two Borael Forests. Canadian Journal of Forest Research 28: $1773-1783$.

13. Janssens IA, Dielaman W, Luyssaert S (2010) Reduction in Forest Soi Respiration in Response to Nitrogen Depletion. Nature Geoscience. 3: 315 322.

14. Berg B, Matzner E (1997) Effect of N Deposition on Decomposition of Plant Litter and Soil Organic Matter in Forest Systems. Env Reviews 5: 1-25.

15. Xu M, Qi Y (2001) Soil Surface CO2 Efflux and its Spatial and Temporal Variations in a Young Ponderosa Pine Plantation in Northern California. Global Change Biol 7: 667-677.

16. Tang J, Qi Y, Xu M, Misson L, Goldstein AH, et al. (2005) Forest Thinning and Soil Respiration in a Ponderosa Pine Plantation in the Sierra Nevada. Tree Physiology. 25: 57-66.

17. Davidson EA, Belk E, Boone RD (1998) Soil Water Content and Temperature as Independent or Confounded Factors Controlling the Soil Respiration in a Temperate Mixed Hardwood Forest. Global Change Biology. 4: 217-277.
18. Keppler F, Hamilton JT, Brass M, Röckmann T (2006) Methane Emissions from Terrestrial Plants Under Aerobic Conditions. Nature. 439: 187-191.

19. Sexstone AJ, Mains CN (1989) Production of Methane and Ethylene in Organic Horizons of Spruce Forest Soils. Soil Biology and Biochemistry 22: 135-139.

20. Megonigal JP, Guenther AB (2008) Methane Emissions from Upland Forest Soils and Vegitation. Tree Physiology 28: 491-498.

21. Megonigal JP, Hines ME, Visscher PT (2004) Anaerobic Metabolism: Linkages to Trace Gases and Aerobic Processes. Biogeochemistry. Schlesinger Elsevier-Pergamon. Oxford.

22. Anderson BL, Bidoglio G, Leip A, Rembges D (1998) A New Method to Study Simultaneous Methane Oxidation and Methane Production in Soils. Global Biogeochem. Cycles. 12: 587-594.

23. Tripathi D, Jiang Y-L, Kumar D (2010) SABP2, a Methyl Salicylate Esterase is Required for the Systemic Acquired Resistance Induced by Acibenzolar-SMethyl in Plants. FEBS Lett 584: 3458-3463. 